\title{
COMMENTARY ON PAPERS DELIVERED ON "THE SUPREME COURT OF CANADA AND THE LAW OF OBLIGATIONS"
}

\author{
D. C. MEDONALD*
}

The speaker noted that the Hon. Emmett Hall, for whom he was substituting, had had experience as a trial judge, a quality he considers desirable in the appellate courts. He then commented on some of the very early cases of the S.C.C., before proceeding to a discussion of Dean Fridman's paper. The speaker discussed aspects in the development of the law relating to trespassers and occupier's liability. He was of the opinion that the S.C.C. was not as mechanistic in its approach to the law of tort as Dean Fridman thought it to be.

In commenting on Dr. Beaudoin's presentation, Mr. Justice McDonald noted that the blame for the lack of weight given to French decisions in matters concerning the Quebec Civil Code droit de délits should not be attributed to the S.C.C. but to the Privy Council.

In concluding, His Lordship observed that the process of applying for leave to appeal to the S.C.C. deserves further study, since the present requirement that the Court dispose of applications for leave which are not accompanied by an oral submission increases the cost of appeal - particularly for Western cases.

I received David Percy's invitation to make these comments just over two weeks ago. Even if I had had two months, I could not have proven a satisfactory substitute for the Hon. Emmett Hall.

Vous savez que le juge Hall est québecois d'origine. Il a parlé français depuis son enfance, et il est très fier d'être québecois en dépit de sa vie adulte en Saskatchewan. Sa carrière judiciaire était un modèle d'innovation hardi du type que nos conférenciers d'aujourd'hui souhaitent comme plus commun dans la Cour suprême du Canada.

In addition to possessing judicial valour, he has been a compassionate judge. That is a quality which good trial judges value and which they know is not easy to achieve. I do not intend to list all his qualities. I will add one more. He had experience as a trial judge. Many members of the bar and most trial judges feel that there should always be a strong representation on our appellate courts of judges who have had experience as a trial judge. At present on the Supreme Court only a minority of the judges have had such experience. A third, the Chief Justice, had considerable experience as a labour arbitrator, which is akin to trial judicial work. It is no disparagement of the abilities of the other members of the court to place before you what is frequently said at the Bar.

That observation is of course particularly pertinent to the court's role in private law matters, including the law of obligations.

Before commenting on this afternoon's papers, I have some historical observations :

1. This celebration of the 100th anniversary of the Supreme Court of Canada is premature. It is true that the Supreme and Exchequer Court Act, by which the Supreme Court of Canada was established, was passed on April 8, 1875. However, while the Proclamation respecting the organization of the Court was issued on September 17, 1875, the Proclamation calling into exercise the judicial functions of the Court was not issued until January 10, 1876. It was only then that the Court really began to function. It was not until June, 1876, that the Court first sat. The first case to be heard, according to the Supreme Court Reports, is the second one reported. The sitting was on June 5,1876 . Only one other case is reported from the June sessions. The next sessions, which were more productive, were held in January, 1877.

- The Honourable Mr. Justice D. C. McDonald, Justice of the Trial Division, Supreme Court of Alberta. 
Since this celebration is premature, I was tempted to say no more. However, that would be rude, so I have a few more notes about the first year of the Court.

2. The fifth case reported, which was argued January 26th 1877, was the first case not involving a question of jurisdiction or practice. It was a criminal law matter, Laliberté v. The Queen, in which the ground of appeal was a question of evidence. The decision of the Court is now under attack by the Evidence Study Project of the Law Reform Commission of Canada. The Court allowed the appeal from the conviction and held that it had no power to order a new trial - a stark reminder to us today that the power of an appellate court to jeopardize the accused a second time is modern and distinctively Canadian - or at least not borrowed from the English. The last point about this case is that counsel for the successful appellant was a young Quebec lawyer named Mr. W. Laurier.

3. In June, 1877, the Court heard a case in which a mortgagee's solicitor's certificate had been given in 1855 by John A. Macdonald, solicitor to the Trust and Loan Company of Upper Canada.

4. Other private law matters considered by the Court in its first year were the right of a pew-holder in a church to continue his lease on the pew, partywall rights in Quebec, prescription and acknowledgment of debt in Quebec, breach of warranty on the sale of goods, the liability of a shareholder to execution creditors of the company, the scope of authority of an insurance agent, and the doctrine of corporate ultra vires.

I turn now to a few comments concerning Dean Fridman's trenchant paper. ... I personally regret that Gerald Fridman is leaving this Faculty, but am pleased that this splendid meeting garlands the eve of his departure.

I intend to refer to only some of Dean Fridman's points.

He criticizes the Supreme Court for adopting the rule established in England in 1818 , that where an offer is made by post, acceptance in the same manner is effective upon posting the acceptance. He suggests that to adopt it in a Quebec case was even worse as not being "bicultural." Yet in his judgment in Magann v. Auger, Taschereau J. did cite one French commentator in support of the rule.

Dean Fridman criticizes the Supreme Court for deciding in Foot v. Rawlings [1963] S.C.R. 197, that giving a creditor a post-dated cheque constituted good consideration for an agreement by the creditor to forbear from suing on promissory notes. Dean Fridman says the Canadian decision is wrong, because in 1966 Lord Denning M.R., in the English Court of Appeal, held the contrary. Does that follow, especially when the Canadian decision is consistent with the recommendation of the English Law Revision Committee in 1937? Perhaps Pinnel's case and Foakes v. Beer are wrong and should be followed no more than necessary in Canada? I presume the Dean disagrees with the Law Revision Committee and the result of the Supreme Court's decision; therefore he considers it wrong.

Dean Fridman has mentioned some aspects of the law relating to occupiers' liability. I add a mention of trespassers. It is true that in a Privy Council case from Canada (Grand Trunk Railway v. Barnett [1911] A.C. 361) and a Supreme Court of Canada case (Herdman v. Maritime Coal Co. (1920) 59 S.C.R. 127) it was held that a railway company owes a trespasser only a duty not to run him down knowingly or recklessly. Yet in another judgment, C.P.R. v. Kizlyk [1944] S.C.R. 98, the majority judgments in the Supreme Court of Canada recognized that where railway cars were being moved, the railway company owed a duty to children known likely to be present (even though trespassers) to see that they 
were not about the cars, and, if they were, to warn them of the impending movement of the cars. Davis J. quoted with approval section 334 of the American Law Institute's Restatement of Torts, which reads as follows:

A possessor of land who knows, or from facts within his knowledge should know, that trespassers constantly intrude upon a limited area thereof, is subject to liability for bodily harm there caused to them by his failure to carry on an activity involving a risk of death or serious bodily harm with reasonable care for their safety.

Both the majority view and that of Davis J. were far in advance of the "duty of common humanity" which was not arrived at in England until British Railways Board v. Herrington [1972] A.C. 87 (H.L.) and in the Privy Council in Southern Parkland Cement Ltd. v. Cooper [1974] 2 W.L.R. 152, [1974] 1 A11 E.R. 87. That test has now been adopted by Dickson J. and two other judges in the Supreme Court of Canada in Veinot v. Kerr Addison Mines Ltd. (1975) 3 N.R. 94, while Martland J. and three of the judges said that in the case of adults the duty is to warn but that in the case of children "something more may be required." Dickson J. did not refer to any earlier Canadian authority. Martland J. did not refer to Kizlyk. The overall result is serious confusion as to what duty is owed to trespassers in Canada.

I should mention that a recent case before the Court, Paskivski v. Canadian Pacific Ltd. [1975] 5 W.W.R. 640 was treated by the Court as not being a case in which the infant plaintiff was a trespasser or indeed as a case of occupier's liability at all. Even so the Supreme Court has been adventurous. The Court held that there were those "special or exceptional circumstances" which earlier decisions of the Court recognized if a duty to use reasonable care were to be imposed on a railway company in addition to its statutory and regulatory duties. However, obiter, the majority, in a judgment delivered by Dickson J., expressed the view that since that rule was formulated in The Grand Trunk Railway Company of Canada v. McKay (1904) 34 S.C.R. 81, "many changes" have been wrought in Canada:

It may well be that the interests of a young and undeveloped nation are best served by a minimum of impediment to industrial growth and economic expansion but in a more developed and populous nation this attitude of laissez faire may have to yield to accommodate the legitimate concern of society for other vital interests such as the safety and welfare of children.

Hence Dickson J. tentatively questioned "the relevance and validity of a rule of law which limits the common law duty of care of a railway to the special case or the exceptional case ....."

Returning to occupier's liability, a question arises whether the Contributory Negligence Acts apply. If the duty owed to an invitee as stated by Willes J. in Indermaur v. Dames (1866) L.R. 1 C.P. 274 at 288 is treated as the gospel, then the duty is owed only to an invitee who uses "reasonable care on his part for his own safety." Again, the duty is only to use reasonable care "to prevent damage from unusual danger." An unusual danger has been held to be one not discoverable by an invitee by the exercise of reasonable care on his part. If the danger is one which is discoverable by the invitee, it might be said that if he fails to discover it, the occupier owes him no duty and the invitee fails completely in his action. The Contributory Negligence Act would not be applicable. In England the point has never been decided. Yet in Greisman v. Gillingham [1934] S.C.R. 37, and Brown v. $B$ and $F$ Theatres Limited [1974] S.C.R. 486, the Supreme Court of Canada, without discussion, applied the Act. Surely this is a just application of the legislative intent. Yet, if the Court were as mechanistic as Dean Fridman suggests, one might have expected the contrary. 
To give credit where credit is due, I refer now to a subject of interest only to Alberta and Manitoba, where, as in England, estates may claim damages for the deceased's loss of expectation of life. In Benham v. Gambling [1941] A.C. 157 , such loss on the death of a $2 \frac{1}{2}$-year-old child was assessed by the House of Lords at $£ 250$ - at that time, $\$ 1,250.00$. Viscount Simon L.C. said that "in assessing damages under this head, whether in the case of a child or an adult, very moderate figures should be chosen." In Bechtold v. Osbaldeston [1953] 2 S.C.R. 177, the plaintiff was 22 at the time of the accident and died a year later, never having regained consciousness. The award upheld by the Supreme Court of Canada was $\$ 7,500.00$. The upward limit for a person in the prime of life is probably now $\$ 10,000.00$ : Crosby v. O'Reilly (1974) 2 N.R. 33. (However, in the recent unreported case of Pollock v. Hilbery in Manitoba, Hamilton J. considered Crosby v. O'Reilly and then awarded $\$ 20,000.00$ damages for loss of expectation where a 56-year-old woman was killed.) The point is that "differences in conditions" in Canada and England were said by Kerwin J. to be properly taken into account, apparently with the result that "the prospect of a predominantly happy life" has been held by the Supreme Court to be worth considerably more in Canada than in England.

Another instance in which credit should be given to the Supreme Court of Canada for independence of thought is the question of damages for a child whose mother has been killed by the defendant's negligence. In Vana v. Tosta [1968] S.C.R. 71, the Supreme Court held that its decision in St. Lawrence \& Ottawa Railway v. Lett (1885) II S.C.R. 422 is still the law in Canada. That is, the heads of loss recoverable include an allowance for the child's loss of its mother's care and guidance. The Court thus refused to follow the contrary position taken in England and Australia: see Fleming on Torts, 4th ed. at 587. Only very recently in England has there been some suggestion, obiter and tentative as it is, that this head of loss may be recognized: see Lord Edmund Davies in Hay v. Hughes [1975] 1 All E.R. 257 at 261 (C.A.).

In these areas of the law of tort then, one may be more charitable to the Court than as to those matters mentioned by Dean Fridman.

Before 1949, the Supreme Court sometimes missed even the opportunity to state its position as to some question before it passed on to the Privy Council. Appeals could be taken per saltum from the provincial appeal court to the Privy Council. For example, the famous case of B. C. Electric Ry. Co. v. Loach [1916] 1 A.C. 719 , which recognized the doctrine of constructive last clear chance, went directly to London from British Columbia. Again, the Supreme Court did not have the opportunity to question whether death ends the right to sue for damages for negligence: in Walpole v. Can. Nor. Ry. [1923] A.C. 113, Viscount Cave L.C. stated the rule in the affirmative, but the case had gone to the Privy Council directly from Saskatchewan.

If it is true that the substantive law of negligence is inextricably entwined with the interstices of procedure, then it is proper for me to refer to one important question as to which the decision of the Supreme Court of Canada was upheld in the Privy Council. Provincial highway traffic statutes place the onus of proof that the loss did not arise through the negligence of the owner or driver of a motor vehicle upon that owner or driver. The Appellate Division in Alberta had treated the statute as if speaking of what we could now call an evidentiary burden. The Saskatchewan Court of Appeal treated it as if speaking of what we would now call the legal burden. In Winnipeg Electric Co. v. Geel [1931] S.C.R. 443, the Supreme Court of Canada adopted the latter view, and the Privy Council agreed ([1932] A.C. 690). This decision has, of course, had a very significant effect on the conduct of motor vehicle litigation. 
Je n'ose rien dire de substantiel au sujet de la conférence du docteur Beaudoin. Le devoir auquel je me suis soumis aujourd'hui m'a donné l'occasion de lire son article deux ou trois fois, et en supplément mon devoir m'a conduit à lire son article dans la Revue du Barreau Canadien de 1966, Le Code civil québecois: crise de croissance ou crise de vieillesse. Sa conférence d'aujourd'hui est une expansion de quelques - unes de ses remarques il y a neuf ans. Mais dans cette article - là, il a employé un mot plus fort que ceux qu'il a employé aujourd'hui en décrivant l'usage du common law par les juges de la Cour suprême dans l'interprétation des textes du Code civil. Le mot est "sournois", et l'adjectif décrit un danger. C'est le docteur Beaudoin qui l'appelle "danger", mais j’accepte sa désignation de l'état des choses.

J'ai eu le temps de lire aussi des articles et de jeter un coup d'oeil sur des livres du professeur Louis Baudouin, sur un article du professeur Azard dans la Revue du Barreau Canadien de 1965, et sur le livre du professeur Castel sur le droit de Québec.

Mais, ayant aussi commencé mon éducation, je reconnais que je n'ai pas le droit de rien ajouter au sujet à ce moment, sauf peut-être de mentionner qu'il ne serait pas mal à propos de ressusciter ici, comme sujet de discussion, les options diverses que l’on a suggérées pour réduire l'influence dans la Cour suprême des juges qui viennent des provinces de langue anglaise sur le développement du droit privé du Québec.

Néanmoins j'ajouterai cette note: la possibilité que les arrêts des tribunaux français dans la domaine du droit de délits soient acceptés comme parmi les facteurs qui pourraient influencer la Cour suprême dans les causes provenant du Québec fut tuée par la décision du Conseil privé dans McArthur v. Dominion Cartridge Company [1905] A.C. 72, d̀ la page 77, où Lord Macnaghten dit:

The learned judges in the Supreme Court appear to have been much influenced by some decisions in France which are stated by Girouard J. to be "unanimous in exacting proof of a fault which certainly caused the injury.' The learned judge had previously observed that 'as to the cause of this explosion ... we are left entirely in the dark.' As recent French decisions, though entitled to the highest respect and valuable as illustrations, are not of binding authority in Quebec, the learned counsel at the bar very properly abstained from examining in detail the cases referred to by Girouard J.

(C'était le juge Girouard qui avait donné la décision de la majorité de la Cour suprême.) Après de telle éloge faible des décisions françaises, il n'est pas remarquable que l'influence des arrêts français dans et sur la Cour suprême a été miniscule. Pour ça, on ne peut pas blâmer la Cour suprême.

In matters of private law at least, it was a common joke among members of the Bar in Alberta before I became a judge, that one could count on the Supreme Court of Canada to restore the judgments of judges of the Trial Division of the Supreme Court of Alberta which had been reversed by the Appellate Division. I have no idea whether the same view is held today. There is a second branch of the theory: that to have a trial judgment upheld by the Appellate Division is to ensure reversal in Ottawa.

These observations are by way of referring to a topic which has been discussed by Professor Abel in the Alberta Law Review in 1965 and Professor Weiler in his recent book: whether the Supreme Court of Canada should be the court of appeal in private law matters which are within the legislative jurisdiction of the provinces. As a judge, I cannot enter that debate, political in nature as it is. I can, however, point to the Alberta mythology which I have mentioned, and which I suspect is neither defunct nor unique, and which tends to suggest that whatever the constitutional arguments may be, the Bar would be unhappy to see the jurisdiction of the Court limited in this respect. 
The emphasis this afternoon on the role of the Supreme Court of Canada in matters of substantive law ought not to cause us to forget to glance at the procedure of getting before the Court. As of this year all appeals will be heard only if leave is first granted by the Court - usually that means by a panel of three judges of the Court. Previously, if the appeal concerned $\$ 10,000$ or more, there was an appeal as of right. Many private law matters which involved more than $\$ 10,000$ but were really questions of fact reached the Court automatically. The process of applying for leave deserves further consideration. In cases where previously leave was unnecessary, it must now be sought. The cost of the appellate process is increased, particularly for cases from the West, especially because of the necessity to appear to make an oral submission. Four years ago, in preparing a brief to be presented to the joint Senate-House of Commons Committee on the Constitution, I retrieved questionnaires from about 125 Alberta lawyers - about one-tenth of the practising Bar of the province. A majority approved a system which exists in the Supreme Court of the United States: that the Court may decline to grant leave, on the basis of written material filed. This response indicates to me that some further look should be taken at permitting the Court - not requiring it - to dispose of applications for leave without oral submissions.

If it is true that the Supreme Court would have some time to devote to careful and comprehensive surveys and statements of the law if it limited itself to matters of law, it follows that the Court ought to change its attitude toward its role in reviewing findings of fact. At present, it subscribes to the view that provincial appellate courts follow, viz. that it can reverse "secondary" findings of fact. This theory has been modified by the Supreme Court by the doctrine of concurrent findings of fact. Yet purely factual cases continue to take the time of the court. A very recent example is Workmen's Compensation Board v. Greer [1975] I S.C.R. 347, where Ritchie J., delivering the judgment of the Court, said:

I appreciate that this conclusion differs from that reached by the trial judge and two of the three judges sitting in the Appeal Division, but no question arises as to the veracity of the witnesses and the judgment of the majority of the Appeal Division is based on inferences drawn from conflicting medical opinion so that this is a case which appears to me to be governed by the language used by Lord Halsbury in Montgomery \& Co. Ltd. v. Wallace-James which was affirmed by the Privy Council in Dominion Trust Co. v. New York Life Insurance Co. Lord Halsbury said in part:

“. . . where no question arises as to truthfulness, and where the question is as to the proper inferences to be drawn from truthful evidence, then the original tribunal is in no better position to decide than the judges of the Appellate Court.

In my opinion, the practice of this Court, which reflects a reluctance to interfere with concurrent findings of fact in two provincial courts, does not apply with the same force to inferences drawn from conflicting professional opinions as it does to findings based on direct factual evidence."

In Hood v. Hood [1972] S.C.R. 244 at 251-4, Laskin J., as he then was, reviewed the conflicting guidelines as to the power of review of findings of fact by appellate courts in general, including the Supreme Court of Canada. Yet even he does not seem to question whether the Supreme Court of Canada should be concerned at all about cases in which the question is one of fact. I suggest that this question does deserve consideration.

En terminant, permettez-moi d'adapter un refrain de Rimbaud:

\section{$\hat{O}$ saisons ! $\hat{O}$ châteaux !}

Quelle cour est sans défauts !

Thus, as a member of your association, I claim the right to urge you to be tolerant of the weaknesses of judges, even those of the Supreme Court of Canada, 
and gentle in the style of your criticism of them both collectively and individually. Remember, unlike the members of other political institutions, our judges are not very free to defend themselves.

It does seem to me that, even allowing for the validity of most of the criticism levelled against the Court by Dean Fridman and Mr. Weiler, among others, the record of the Court in private law matters from the common law provinces has not been demonstrated to have resulted in quantitatively significant injustice. Considering the constraints placed upon the Court by its tradition of regional representation and by the innate conservatism of the Canadian legal profession, it is true to say - if I may adapt Dr. Johnson's description of the dog that walked on its hind legs - that the wonder is not that the court has concerned itself with matters of purely private law, but that it has done so not badly at all. 